\title{
The science of bird conservation
}

\author{
T. M. BROOKS, N. J. COLLAR, R. E. GREEN, S. J. MARSDEN and D. J. PAIN
}

\section{Introduction}

Colin Bibby (1948-2004) was the quintessential bird conservation biologist. Over his career, he served as lead scientist at two of the world's largest bird conservation organizations, the Royal Society for the Protection of Birds, and BirdLife International. His contributions encompassed detailed autecological studies of rare bird species such as the Dartford Warbler Sylvia undata (e.g. Bibby 1978) and Fuerteventura Stonechat Saxicola dacotiae (e.g. Bibby and Hill 1987), a sweeping synthesis of the techniques of bird conservation science (Bibby et al. 1992, 2000), and pioneering contributions in conservation planning such as the Endemic Bird Areas concept (ICBP 1992).

This memorial volume of Bird Conservation International seeks to reflect the breadth of Colin's legacy by presenting papers illustrating the role of ornithological science in saving threatened birds, reviews of novel field and analytical techniques, and syntheses of progress with the development of bird conservation strategies. In the first category, we include studies of albatrosses (Croxall et al.), South Asian vultures (Pain et al.), migratory species (Kirby et al.), and the Northern Bald Ibis Geronticus eremita (Bowden et al.). In the second, we have reviews of surveying bird abundance (Buckland et al.), bird-habitat associations (Lee and Marsden), fluctuating asymmetry (Lens and Eggermont), camera trapping ( $\mathrm{O}^{\prime}$ Brien et al.), automated sound recording (Brandes), stable isotopes (Hobson), and socio-economic surveys (MacMillan and Leader-Williams). Finally, we document progress in three key tools for bird conservation planning: atlases (Pomeroy et al.), population indices (Gregory et al.), and the IUCN Red List of threatened bird species (Butchart). We hope that this span from the specifics to the generalities of bird conservation science provides a fitting tribute to Colin's life and work.

To set the context for this tribute, however, we take advantage of our editorial privilege to reflect on the state of bird conservation science, and to assess its future potential. The urgency of the task faced by bird conservation science should not be underestimated. No fewer than 1,226 species of birds, out of 9,856 extant species, are threatened with extinction, almost one eighth of the total (BirdLife International 2008a). However, rates of endangerment for other vertebrate classes are worse (Baillie et al. 2004). To what extent is conservation science delivering the scientific knowledge necessary to save those 1,226 threatened birds-and indeed, biological diversity more generally?

In this essay, we tackle five aspects of this question. First, we use information from the Handbook of the birds of the world to assess the prevalence of threatened species studies. Because the intensity of study varies greatly across threatened species, we then explore some factors that correlate with and might help explain this variation. Third, we switch data source to this very journal, specifically manuscripts published in Bird Conservation International over the last five years, to ask where conservation ornithologists come from. We continue this line of enquiry to examine the kinds of questions being pursued concerning threatened bird species. Finally, we speculate on the importance of bird conservation science as a pioneer and model for conservation science in general. We conclude with some suggestions for future priorities for bird conservation science as a discipline.

\section{Threatened and non-threatened birds: which are studied more?}

To address this question, we selected 50 threatened and 50 non-threatened species at random from the four volumes (nos. 4-7, 1997-2002) of the Handbook of the birds of the world that deal 
with 'near-passerines' (sandgrouse to woodpeckers). The selection of these volumes was driven by the fact that these represent a body of information not greatly influenced by changing publication standards over time, and involving many families and authors. We checked the bibliography at the end of each species account for what we call 'dedicated' references, i.e. those that focus on the species in question (criterion: name of the species in the title, discounting original descriptions, nomenclatural issues and fossil records). We also counted all the other references every time they were cited.

Non-threatened species have $23 \%$ more references per species than threatened species, indicating a broader general information base, probably reflecting their wider ranges, greater abundances and less specialized use of habitat (Table 1 ). Moreover, a greater proportion of nonthreatened species have at least one dedicated reference than do threatened species. On the other hand, threatened species have $21 \%$ more dedicated papers per species, overall, than nonthreatened species, perhaps because threatened species are more likely to be the subject of detailed studies of their status or causes of endangerment. This tendency is even more marked for those species which have been the subject of any dedicated studies. When species with no dedicated studies are excluded, threatened species prove to have more than $50 \%$ more dedicated references per species than non-threatened species.

A possible interpretation of these results is that threatened species are less likely than nonthreatened species to be the subject of general and comparative studies, and more likely to be the subject of studies that concentrate on them as single species. Threatened species tend to have smaller geographical ranges than non-threatened species, and are disproportionately distributed in tropical countries and on islands with few resident ornithologists. They are therefore less accessible to scientific inquiry. On the other hand, once the plight of a particular species is recognized, conservation-oriented scientists may be stimulated to work on it and to recommend and monitor remedial action. The level of detail of scientific data available on a few threatened species is 15 often much higher than for typical non-threatened members of the group to which they belong. For example, more data exist for the Kakapo Strigops habroptilus than for any of the other 350 species of parrots, perhaps because it was the only parrot species classified as 'Extinct in the Wild' in the first comprehensive IUCN assessment (Collar 1998). It is currently extant on offshore islands outside its historical range.

\section{Why are some threatened species studied more than others?}

We compared the 50 threatened species in an attempt to determine the characteristics of those that had greater numbers of total and dedicated references than others. We investigated the influence of five independent variables.

IUCN Threat category - 'Vulnerable', 'Endangered' and 'Critically Endangered'

Table 1. References listed for 50 non-threatened and 50 threatened species of near-passerine birds in del Hoyo et al. (1997-2002). A dedicated reference is one in which the name of the species appears in the title.

\begin{tabular}{llc}
\hline & non-threatened & threatened \\
\hline total references & 1,434 & 1,166 \\
total dedicated references & 184 & 223 \\
$\%$ dedicated references & 12.8 & 19.1 \\
$\%$ species with at least one dedicated & 62 & 50 \\
reference & & \\
mean references per species & $28.7 \pm 19.2 \mathrm{SD}$ & $23.3 \pm 13.3$ \\
mean dedicated references per species & $3.7 \pm 6.9 \mathrm{SD}$ & $4.5 \pm 9.0$ \\
mean dedicated references per species, & $5.9 \pm 8.0 \mathrm{SD}$ & $8.9 \pm 11.1$ \\
excluding species with no dedicated & & \\
references & & \\
\hline
\end{tabular}


Log range size - Log-transformed estimated range size taken from www.birdlife.org/datazone/ species.

Island/mainland - Whether the taxon occurs on a single island with land area $<20$, $000 \mathrm{~km}^{2}$, or not.

Log body size - Log-transformed mean length of bird as given in www.birdlife.org/datazone/ species.

Log per capita income of range country/ies - Log-transformed values of per capita income taken from www.worldbank.org except for Guam (ns.gov.gu/indicators.html). Means were taken where a species' range falls into more than country except when its occurrence in the second country was marginal.

The total number of references for threatened species was strongly correlated with the number of dedicated references $\left(r_{\mathrm{s}}=+0.79, P<0.0001, n=50\right)$, so we analysed only the logtransformed total number of references. Numbers of references were not significantly correlated with body size $(r=+0.24, \mathrm{df}=48, P=0.10)$ or with range size $(r=-0.16, \mathrm{df}=48, P=0.27)$. There was, however, a significant positive relationship between total references and per capita income of range country/ies $(r=+0.31, \mathrm{df}=48, P=0.03$; Figure 1$)$.

The number of references was significantly lower for island species (mean $=18.8 \pm 13.6$ ) than for mainland species (mean $=25.3 \pm 12.9$; $t$-test on log-transformed value, $t=2.46, \mathrm{df}=$ $48, P=0.02)$. Numbers of references per species varied significantly among threat status $\left(F_{2,47}\right.$ $=4.4, P=0.018$ ). 'Critically Endangered' species had far more references (mean $=32.4 \pm 18.1$ ) than 'Vulnerable' (mean $=19.9 \pm 8.7$; Bonferroni post hoc test; $P=0.032$ ) and 'Endangered' species (mean $=19.7 \pm 9.8 ; P=0.04$ ). This mirrors the recent and important finding that conservation activity is greater for species in higher threat categories (Brooke et al. 2008).

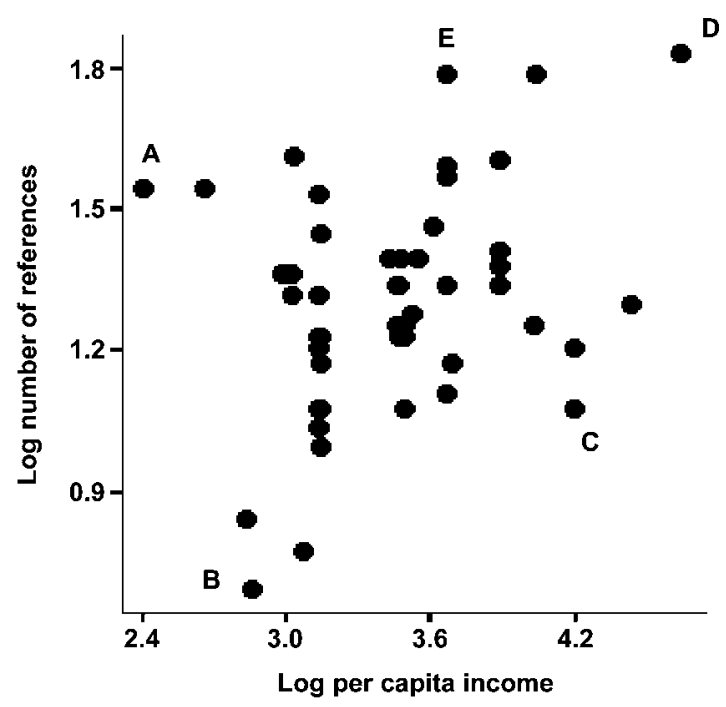

Figure 1. The relationship between numbers of references for a random sample of 50 threatened species and per capita income in their range countries. The following points are marked for interest: A Rufous Fish-owl Scotopelia ussheri (Guinea, Sierra Leone, Liberia, Côte d'Ivoire and Ghana PCI $=$ US\$438); B New Britain Bronzewing Henicophaps foersteri (Papua New Guinea PCI = US\$740); C Polynesian Imperial-pigeon Ducula aurorae (French Polynesia, $\mathrm{PCI}=\mathrm{US} \$ 16,070) ; \mathrm{D}$ Ivory-billed Woodpecker Campephilus principalis (U.S.A. PCI $=\mathrm{US} \$ 44,710)$; E Spix's Macaw Cyanopsitta spixii (Brazil PCI $=\mathrm{US} \$ 4,710)$. 
The most worrying consideration is, of course, that so many threatened species attract so little attention. In our analysis, $50 \%$ of threatened species have not a single publication dedicated to them; by extrapolation, this amounts to over 600 species of bird. Clearly, studies of some of these species will be particularly problematic or challenging, perhaps occurring in politically unstable areas, or so elusive that encounter rates are completely unpredictable. While the study of each of these species will present its own combination of challenges, be these logistic, financial, administrative or 'political', the need to study and understand them is urgent as a first step towards ensuring their long-term survival. BirdLife International and BirdLife partner organizations in the countries in question will always be willing to provide advice and, where possible, help.

\section{Who is studying threatened species?}

We examined all papers appearing in Bird Conservation International (standard issues only) for the period 2004-2008 in order to identify the affiliations of authors of the 144 papers published during that period. Each paper was classified according to the address given by the corresponding author as either from a low or a high income country (World Bank definition with lower-middle income countries combined with low income countries, and upper-middle income countries combined with high income countries) and from one of the following: university; research institute/museum; non-governmental organization including BirdLife partner; government agency; independent scientist; or consultancy. It was also noted, for each paper, the number of different institutions (e.g. university, NGO) that were given among the paper's authors.

Altogether, $114(79 \%)$ of the papers published had corresponding authors from high income countries. Universities and research institutes produced $76 \%$ of published papers, with NGOs $(14 \%)$, governmental bodies ( $8 \%$ ), especially those from Australasia and the US, producing all but a tiny proportion of the remainder (Figure 2). While academics dominated lead authorship on these papers, nearly half of papers were produced by authors from more than one institution type, with $13 \%$ originating from three or more institution types (e.g. Simmons et al. 2007). The most common partnerships were between universities and NGOs, but governmental bodies (e.g. government wildlife departments and protected area management bodies) were also well represented.

Most threatened bird species inhabit low income countries (www.birdlife.org/datazone/ species), so the fact that only around $20 \%$ of published papers come from such countries reflects a continuing lack of conservation science resources and capacity in the places where threatened species are found.

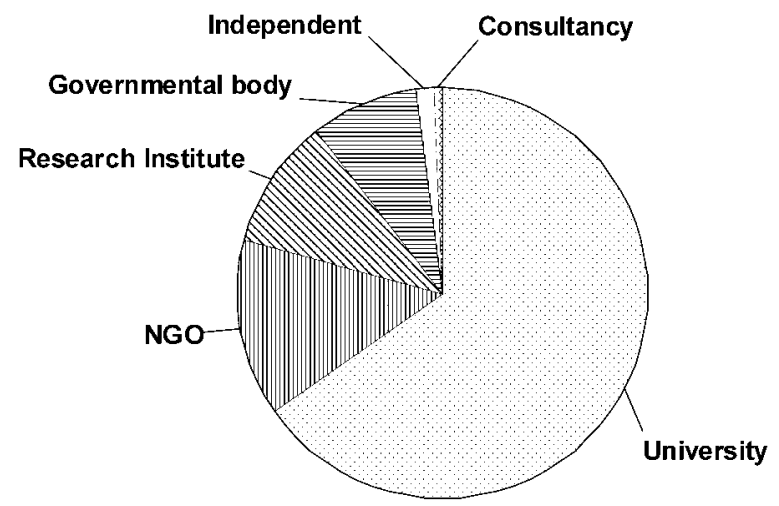

Figure 2. Addresses given by the corresponding authors of 144 papers published in the journal Bird Conservation International 2004-8. 


\section{What scientific questions are asked about threatened bird species?}

Using the same 144 manuscripts published in Bird Conservation International 2004-2008, we assessed the following characteristics of each paper:

Issue addressed - Each paper was categorised according to its main theme as one of the following: species status (includes counts, population estimates, and identification of declines); distribution (including range definitions and extensions, biogeographical studies); habitat associations; ecology (including breeding studies, diet, movements, behaviour etc); threats (papers dealing with a specific threat to one or more species); methodological; taxonomic; genetic; socioeconomic (including interviews, livelihood and economic studies); captive breeding; and effects of specific conservation actions (releases, legal protection etc).

Region - Each paper was categorised according to region, following BirdLife International (www.birdlife.org/datazone/species).

Specificity - Papers were categorised according to whether they dealt with: single species; a single taxonomic group (e.g. a genus, family or assemblage such as waders); multi-species (e.g. response of a bird community to environmental change); site-based topics (e.g. inventories of protected areas); or national topics (e.g. Batáry et al. 2007).

The mainstay of papers published in Bird Conservation International remains those that address the population status of species, many of them dealing with just one species $(66 \%)$ or taxon/bird group (12\%). It is encouraging that there are now also many papers that focus on the ecological requirements of birds and their habitat associations (Table 2). Notably few are studies of socioeconomic aspects of bird conservation (the only paper being Baral and Gautam 2007), and the practice of in-situ and ex-situ conservation (e.g. Klein et al. 2007).

Table 3 shows the breakdown of papers according to region, along with the number of threatened birds recognized from that region by BirdLife International (www.birdlife.org/ datazone/species). The greatest numbers of publications deal with birds from Asia, South America, Africa and Europe. Numbers of papers varied greatly across regions, with the Middle East, Oceania and Caribbean having 'publication rates' 2-3 times lower than those of Asia, Central America and Africa. Submission rates to this journal are affected by the existence of competing conservation and ornithological journals in some regions, as well as the number of studies carried out. This is likely to be the main reason for the small number of submitted studies per species from North America. However, the results suggest that birds in, for example, Asia and Africa are more often being studied in a conservation context than threatened birds in some other regions. Data from South America suggest that, despite a significant number of publications from the region, efforts are swamped by the huge number of threatened taxa within the continent.

Table 2. The principal issue dealt with by the 144 papers published in Bird Conservation International during the period 2004-2008.

\begin{tabular}{ll}
\hline Issue & Number of papers \\
\hline Species status - includes population estimates, declines & $62(43 \%)$ \\
Ecology - includes breeding & $29(20 \%)$ \\
Threats - papers dealing with a specific threat & $17(12 \%)$ \\
Habitat associations & $16(11 \%)$ \\
Taxonomy & $6(4 \%)$ \\
Methodological & $4(3 \%)$ \\
Captive breeding & $3(2 \%)$ \\
Genetics & $3(2 \%)$ \\
Results of conservation actions & $3(2 \%)$ \\
Socio-economic studies & $1(1 \%)$ \\
\hline
\end{tabular}


Table 3. Breakdown of papers published in BCI (2004-8) by region along with the number of threatened birds recognized from that region by BirdLife International (data from www.birdlife.org/datazone). 'Extinct' (EX) but not 'Extinct in the Wild' (EW) species have been excluded. Regions have been ranked according to their score in the final column. Two papers dealing with global issues were excluded.

\begin{tabular}{lccl}
\hline Region & $\begin{array}{l}\text { No. threatened } \\
\text { species }\end{array}$ & No. BCI papers & $\begin{array}{l}\text { No. papers per } \\
\text { threatened species }\end{array}$ \\
\hline Europe & 23 & 22 & 0.96 \\
Asia & 334 & 42 & 0.13 \\
Central America & 79 & 9 & 0.11 \\
Africa & 232 & 25 & 0.11 \\
South America & 338 & 5 & 0.08 \\
North America & 73 & 1 & 0.07 \\
Central Asia & 24 & 3 & 0.04 \\
Oceania & 78 & 3 & 0.04 \\
Marine & 79 & 5 & 0.04 \\
Australasia & 171 & 1 & 0.03 \\
Caribbean & 54 & 0 & 0.02 \\
Middle East & 27 & 0 & 0 \\
Antarctica & 13 & & 0 \\
\hline
\end{tabular}

\section{The leading role of bird conservation science}

Birds are better loved, known and studied than any other class of organisms. Hence, conservation ornithology might be expected to play a leading role in the development of conservation science in general. Four lines of evidence suggest that the discipline has so far lived up to this prediction.

First, considering the development of atlases of species distributions (see Pomeroy et al.), we searched the popular Natural History Book Service (www.nhbs.com) website for the keywords 'atlas' and '[taxonomic group]' to determine the extent of bird atlas work relative to other taxa. Birds win hands down: 127 bird atlases are listed, compared to only 69 for plants, 26 for reptiles, 21 for butterflies, 18 for amphibians, 17 for mammals (surprisingly), and 6 for dragonflies. Population indices are a second area where ornithology seems to be making great contributions towards conservation policy and planning (Gregory et al.). To assess this, we considered the relative role of bird data in developing the Living Planet Index. They prove overwhelmingly important: $778(59 \%)$ of the 1,313 datasets incorporated in the 2006 Living Planet Index (WWF 2006) are avian.

A third category in which bird conservation science has led conservation biology generally is the identification of sites of global conservation significance. This challenge was taken up for birds in Europe in the 1980s (Grimmett and Jones 1989), using the principles of irreplaceability and vulnerability that remain the cornerstones of systematic planning today (Margules and Pressey 2000) to identify Important Bird Areas (IBAs). The IBA programme now has coverage that is globally near-comprehensive, with 6,460 sites identified in 167 countries (BirdLife International 2004a). This work has led to the emergence of similar programmes for the identification of Prime Butterfly Areas (van Swaay and Warren 2003), Important Plant Areas (Plantlife International 2004), and Important Sites for Freshwater Biodiversity (Darwall and Vié 2005) over the last decade. These in turn are now consolidating under the label of 'Key Biodiversity Areas' (Eken et al. 2004, Langhammer et al. 2007), including for amphibians (Silvano et al. 2007), marine species (Edgar et al. 2008) and highly threatened species (Ricketts et al. 2005).

Finally, we consider the IUCN Red Lists themselves (Butchart). Two decades ago, birds were the first taxonomic class to be comprehensively evaluated for threat status against repeatable criteria (Collar and Andrew 1988). A second such evaluation followed six years later (Collar et al. 
1994) using the draft quantitative criteria for the IUCN Red List (Mace and Stuart 1994), with further detailed reviews at now regular intervals (BirdLife International 2000, 2004b, 2008a), the latter two based on the finalized formal IUCN Red List categories and criteria (IUCN 2001). Comprehensive evaluation of other groups has lagged well behind that for birds. Mammals were first evaluated in 1996, but not comprehensively; this remains a few months away with the planned launch of the Global Mammal Assessment in late 2008. The first Global Amphibian Assessment was completed in 2004 (Stuart et al. 2004, IUCN et al. 2006), and three further such projects are now underway: the Global Reptile Assessment; the Global Freshwater Biodiversity Assessment (covering fish, molluscs, dragonflies, decapod crustaceans and freshwater plants); and the Global Marine Species Assessment (covering fish, and habitat-forming species including corals, mangroves, seagrasses and macroalgae).

However, whilst ornithology has provided leadership in some areas of conservation science, its record is uneven. Online taxonomic databases have been developed and posted considerably faster for many other taxa, including mammals (Wilson and Reeder 2005; nmnhgoph.si.edu/ $\mathrm{msw} /$ ), reptiles (Uetz 2008; www.reptile-database.org/), amphibians (Frost 2007; research.amnh. org/herpetology/amphibia/index.php), and fish (Froese and Pauly 2008; www.fishbase.org). Moreover, comprehensive digital GIS polygon range maps have been freely available for some taxa, such as amphibians (IUCN et al. 2006; www.natureserve.org/getData/amphibianMaps.jsp), for some time. Equivalent taxonomic databases have only just become available online for birds (BirdLife International 2008b) and spatial data on the distributions of the world's birds are still not yet available. A further interesting question is the degree to which ornithology plays a leading role in the development of field techniques as well as conservation tools. Some evidence presented here, e.g., for automated sound recording (Brandes), fluctuating asymmetry (Lens), and stable isotopes (Hobson), suggests that this may be the case, although, as in the case of camera trapping $\left(\mathrm{O}^{\prime}\right.$ Brien et al.), it is clearly not always so.

\section{Prospects for conservation ornithology}

We have shown that ornithologists have led the way in many fields of conservation science. However, we have also shown that there are huge gaps in our knowledge of threatened birds, and have identified where these gaps might be most cavernous.

- Many threatened bird species remain unstudied;

- Most studies document status, while relatively few studies deal with the socio-economic aspects of bird conservation, conservation practice and the results of conservation action;

- Respecting regional proportions of threatened bird species, few studies appear to come from Central America, the Caribbean, and the Pacific.

So is it within our reach to fill these gaps, develop the way in which we study threatened birds and, most importantly, build capacity within those countries that have large numbers of threatened birds but not enough people studying and protecting them?

We certainly believe that one of the keys to taking on these challenges is to provide motivation and momentum within the academic world to work on threatened birds and the issues they face. A glance back at Figure 2 might suggest that universities both from high and low income countries are already involved in a good deal of conservation-based bird research. That is true, of course, but there are a huge number of universities worldwide (in August 2007 there were 106 universities and an even higher number of other higher education institutions in the UK alone: www.universitiesuk.ac.uk). Perhaps more helpful than a simple "must work harder" prescription is to look at ways in which we might promote further work in academic circles. First, and most important, the links between academia and NGOs could and should be strengthened. Such partnerships are crucial in the production and dissemination of bird study data, and ultimately in species conservation.

NGOs need to acknowledge, as most already do, that (I) conservation, while a social and political process, will fail unless it is informed by good science, and (2) the cost and value of good 
science should not be underestimated. NGOs and others need to exert pressure on governments to ensure that conservation science is better resourced, through enhanced funding to research councils and universities, and through direct grants from government departments, such as the Darwin Initiative for the Survival of Species run by the UK Department of the Environment, Food and Rural Affairs. Economic analyses illustrating the value of birds to society will help raise the profile and perceived importance of this discipline.

Academics and students should be encouraged to tackle more practical conservation questions. At the most fundamental level, conservation is underpinned by the science of taxonomy, which identifies the entities which may require conservation action and their evolutionary distinctiveness. Distributional studies, population surveys, and studies of habitat associations form the basic currency of conservation ecology; the results may not always make it into toprated journals but study design, implementation and analysis can be surprisingly challenging (e.g. Buckland et al., Lee and Marsden) and constitute excellent exercises in how to do science for students at all levels. Whilst documenting the status of species is essential, we must not fall into the trap of monitoring species to extinction at the expense of taking action to save them. Identifying and demonstrating factors that limit species' populations and finding explanations for population declines are essential, and often require considerable intellectual input or 'high science' and a good deal of academic creativity. In these respects, conservation science is no different from any other scientific discipline; it requires everything from basic demographic data collected using established techniques to innovative and challenging analyses.

Academics and NGOs need to work together at all stages, to frame the most important bird conservation questions, to solve problems and develop solutions. This must be done with sufficient understanding of social and political context to enable change. When this type of collaborative process can be made to work, solutions can be implemented with remarkable rapidity (e.g. Pain et al.).

To achieve increased bird research capacity within academia and beyond, due credit needs to be given to those collecting and writing up the results of studies of threatened birds. Ensuring results are published is one aspect of this and one that is in the blood of academics-again, an argument for building stronger links with NGOs. But authors, organizations, and BirdLife itself have a responsibility to ensure that individuals' hard-earned information does not disappear anonymously into their global-scale publications, and that primary references within other references are properly cited and not forgotten.

Most important for the future is that we build capacity within lower income countries, not just to provide information on threatened birds but, crucially, to allow nationals to take control of the production of this information and to lead the advocacy and implementation of the resultant conservation measures that are identified. By this we mean of course not just training to a level of competency but working with key scientists from such countries to empower agenda-setting, information production and training. Universities in partnership with major NGOs hold the key to high-level capacity building in the discipline of conservation ornithology. Let us conclude with a recommendation for how this key could be used. We urge every academic ornithologist in the world to embark on a study of one under-studied threatened species, with research designed in collaboration with NGOs, and conducted by, or at a minimum involving, a student from one of the species' range countries. Such capacity building is the major challenge for the coming years, and will require major ingenuity, effort, and courage from all parties, but we believe that it is a challenge to which ornithologists with Colin Bibby's vision must rise.

\section{References}

Baillie, J. E. M., Bennun, L. A., Brooks, T. M., Butchart, S. H. M., Chanson, J. S., Cokeliss, Z., Hilton-Taylor, C., Hoffmann, M., Mace, G. M., Mainka, S.
A., Pollock, C. M., Rodrigues, A. S. L., Stattersfield, A. J. and Stuart, S. N. (2004) A global species assessment. Gland, Switzerland: IUCN. 
Baral, N. and Gautam, R. (2007) Socioeconomic perspectives on the conservation of Critically Endangered vultures in South Asia: an empirical study from Nepal. Bird Conserv. Internatn. 17: 131-140.

Batáry, P., Báldi, A. and Erdós, S. (2007) The effects of using different species conservation priority lists on the evaluation of habitat importance within Hungarian grasslands. Bird Conserv. Internatn. 17: 35-44.

Bibby, C. J. (1978) Conservation of Dartford Warbler on English lowland heaths review. Biol. Conserv. 13: 299-307.

Bibby, C. J. and Hill, D. A. (1987) Status of the Fuerteventura Stonechat Saxicola dacotiae. Ibis 129: 491-498.

Bibby, C. J., Burgess, N. D. and Hill, D. A. (1992) Bird census techniques. London: Academic Press.

Bibby, C. J., Burgess, N. D., Hill, D. A. and Mustoe, S. A. (2000) Bird census techniques. Second edition. London: Academic Press.

BirdLife International (2000) Threatened birds of the world. Barcelona: Lynx Edicions.

BirdLife International (2004a) State of the world's birds 2004. Cambridge: BirdLife International [www.birdlife.org/action/ science/sowb].

BirdLife International (2004b) 2004 Threatened birds of the world. Cambridge: BirdLife International [www.birdlife.org/datazone/species].

BirdLife International (2008a) 2008 Threatened birds of the world. Cambridge: BirdLife International [www.birdlife.org/datazone/species].

BirdLife International (2008b) The BirdLife checklist of the birds of the world with conservation status and taxonomic sources. Version I [www.birdlife.org/datazone/ species/downloads/BirdLife_Checklist_ Version_1.xls].

Brooke, M. de L., Butchart, S. H. M., Garnett, S. T., Crowley, G. M., Mantilla-Beniers, N. B. and Stattersfield, A. J. (2008) Rates of movement of threatened bird species between IUCN Red List categories and toward extinction. Conserv. Biol. 22: $417-427$.
Collar, N. J. (1998) Information and ignorance concerning the world's parrots: an index for twenty-first century research and conservation. Papageienkunde 2: 201-235.

Collar, N. J. and Andrew, P. A. (1988) Birds to watch. Cambridge: International Council for Bird Preservation.

Collar, N. J., Crosby, M. J. and Stattersfield, A. J. (1994) Birds to Watch 2 - The world list of threatened birds. Cambridge: BirdLife International.

Darwall, W. R. T. and Vié, J.-C. (2005) Identifying important sites for conservation of freshwater biodiversity: extending the species-based approach. Fisheries Manage. Ecol. 12: 287-293.

del Hoyo, J., Elliott, A. and Sargatal, J., eds. (1997) Handbook of birds of the world, 4: sandgrouse to cuckoos. Barcelona: Lynx Edicions.

del Hoyo, J., Elliott, A. and Sargatal, J., eds. (1999) Handbook of birds of the world 5: barn owls to hummingbirds. Barcelona: Lynx Edicions.

del Hoyo, J., Elliott, A. and Sargatal, J., eds. (2001) Handbook of birds of the world 6: mousebirds to hornbills. Barcelona: Lynx Edicions.

del Hoyo, J., Elliott, A. and Sargatal, J., eds. (2002) Handbook of birds of the world 7 : jacamars to woodpeckers. Barcelona: Lynx Edicions.

Edgar, G. J., Langhammer, P. F., Allen, G., Brooks, T. M., Brodie, J., Crosse, W., De Silva, N., Fishpool, L. D. C., Foster, M. N., Knox, D. H., McCosker, J. E., McManus, R., Millar, A. J. K. and Mugo, R. (2007) Key Biodiversity Areas as globally significant target sites for the conservation of marine biological diversity. Aquatic Conserv. Mar. Freshw. Ecosyst (doi: 10.000/aqc.902).

Eken, G., Bennun, L., Brooks, T. M., Darwall, W., Fishpool, L. D. C., Foster, M., Knox, D., Langhammer, P., Matiku, P., Radford, E., Salaman, P., Sechrest, W., Smith, M. L., Spector, S. and Tordoff, A. (2004) Key Biodiversity Areas as site conservation targets. BioScience 54: 1110-1118.

Froese, R. and Pauly, D. (2008) FishBase. Los Baños, Philippines: WorldFish Center [www.fishbase.org]. 
Frost, D. R. (2007) amphibian species of the world. New York: merican Museum of Natural History. A. [research.amnh.org/ herpetology/amphibia/index.php].

Grimmett, R. F. A. and Jones, T. A., eds. (1989) Important Bird Areas in Europe. Cambridge, UK: International Council for Bird Preservation (Techn. Publ. 9).

ICBP (1992) Putting biodiversity on the map. Cambridge: International Council for Bird Preservation.

IUCN (2001) IUCN Red List categories and criteria - version 3.1. Gland, Switzerland: IUCN [http://www.iucn.org/themes/ssc/ redlists/RLcats2001booklet.html].

IUCN, CI, and NatureServe (2006) Global amphibian assessment. Gland, Switzerland: IUCN [www.globalamphibians.org].

Klein, Á., Nagy, T., Csörgő, T. and Mátics, R. (2007) Exterior nest-boxes may negatively affect Barn Owl Tyto alba survival: an ecological trap. Bird Conserv. Internatn. 17: 273-282.

Langhammer, P. F., Bakarr, M. I., Bennun, L. A., Brooks, T. M., Clay, R. P., Darwall, W., De Silva, N., Edgar, G. J., Eken, G., Fishpool, L. D. C., Fonseca, G. A. B. da, Foster, M. N., Knox, D. H., Matiku, P., Radford, E. A., Rodrigues, A. S. L., Salaman, P., Sechrest, W. and Tordoff, A. W. (2007) Identification and gap analysis of Key Biodiversity Areas. Gland, Switzerland: IUCN [www.iucn.org/dbtwwpd/edocs/PAG-o15.pdf].

Mace, G. M. and Stuart, S. (1994) Draft IUCN Red List categories. Species 21-22: 13-24.

Margules, C. R. and Pressey, R. L. (200o) Systematic conservation planning. Nature 405: 243-253.

Plantlife International (2004) Identifying and protecting the world's most important plant areas. Salisbury, UK: Plantlife International.

Ricketts, T. H., Dinerstein, E., Boucher, T., Brooks, T. M., Butchart, S. H. M., Hoffmann, M., Lamoreux, J. F., Morrison,
J., Parr, M., Pilgrim, J. D., Rodrigues, A. S. L., Sechrest, W., Wallace, G. E., Berlin, K., Bielby, J., Burgess, N. D., Church, D. R., Cox, N., Knox, D., Loucks, C., Luck, G. W., Master, L. L., Moore, R., Naidoo, R., Ridgely, R., Schatz, G. E., Shire, G., Strand, H., Wettengel, W. and Wikramanayake, E. (2005) Pinpointing and preventing imminent extinctions. Proc. Natl. Acad. Sci. U.S.A. 102: 18497-18501.

Silvano, D., Angulo, A., Carnaval, A. C. O. Q. and Pethiyagoda, R. (2007) Designing a network of conservation sites for amphibians - Key Biodiversity Areas. Pp. 12-15 in C. Gascon, J. P. Collins, R. D. Moore, D. R. Church, J. E. McKay and J. R. Mendelson III, eds. Amphibian conservation action plan. Gland, Switzerland: IUCN [www.iucn.org/dbtw-wpd/edocs/2007-013. pdf].

Simmons, R., Baker, N., Braby, R., Dodman, T., Nasirwa, O., Tyler, S., Versfeld, W., Wearne, K. and Wheeler, M. (2007) The Chestnut-banded Plover is an overlooked globally Near Threatened Species. Bird Conserv. Internatn. 17: 283-293.

Stuart, S. N., Chanson, J. S., Cox, N. A., Young, B. E., Rodrigues, A. S. L., Fischman, D. L. and Waller, R. W. (2004) Status and trends of amphibian declines and extinctions worldwide. Science 306: $1783-1786$.

Uetz, P. (2008) The TIGR reptile database. Rockville, USA: The Institute for Genomic Research [www.reptile-database.org/].

van Swaay, C. A. M. and Warren, M. S. (2003) Prime butterfly areas in Europe. Wageningen, Netherlands: National Reference Center for Agriculture, Nature and Fisheries.

Wilson, D. E. and Reeder, D. M. (2005) Mammal species of the world. Baltimore: Johns Hopkins University Press [nmnhgoph.si.edu/msw/].

WWF (2006) Living planet report 2006. Gland, Switzerland: WWF. 


\section{T. M. BROOKS}

Center for Applied Biodiversity Science, Conservation International, 2011 Crystal Drive, Suite 500, Arlington, Virginia 22202, U.S.A.; World Agroforestry Center (ICRAF), University of the Philippines Los Baños, Laguna 4031, Philippines; and University of Tasmania, Hobart TAS 7001, Australia.

\section{N. J. COLLAR}

BirdLife International, Wellbrook Court, Girton Road, Cambridge CB3 oNA, U.K.

\section{R. E. GREEN}

Royal Society for the Protection of Birds and Conservation Science Group, Department of Zoology, Cambridge CB2 zEJ, U.K.

\section{S. J. MARSDEN}

Department of Environmental and Geographical Sciences, Manchester Metropolitan University, Chester Street, Manchester MI 5GD, U.K.

D. J. PAIN

Wildfowl \& Wetlands Trust, Slimbridge, Gloucestershire GL2 $7 B T$, U.K. 